Original Research Paper

\title{
IoT-Based Waste Height and Weight Monitoring System
}

\author{
${ }^{1}$ Tedi Gunawan, ${ }^{2}$ Elis Hernawati and ${ }^{3}$ Bayu Rima Aditya \\ ${ }^{1,2,3}$ School of Applied Science, Telkom University, Bandung, Indonesia
}

\author{
Article history \\ Received: 24-06-2021 \\ Revised: 13-09-2021 \\ Accepted: 28-09-2021 \\ Corresponding Author: \\ Tedi Gunawan \\ School of Applied Science- \\ Telkom University, Bandung, \\ Indonesia \\ Email: tedigunawan@telkomuniversity.ac.id
}

\begin{abstract}
Over the past decade, the use of smart waste monitoring systems has become a popular way of waste management. This system generally makes it easier for scavengers and household users to monitor the status of the level of waste in the trash. This study aims to create an innovative IoT-based intelligent waste monitoring system to facilitate waste monitoring for households. The proposed system consists of the first 3 important parts, an IoT-based household trash bin monitoring system. Second, the smart trash can monitor system uses 2 sensors, namely ultrasonic sensors and load cell sensors. Third, display a full indicator on the web if it has reached the maximum height or weight limit of garbage. Meanwhile, the evaluation of the system is carried out by testing the accuracy of the weight and height values of the waste on the smart waste system and using the black-box method for testing application features. The proposed smart trash bin has been tested manually using a ruler for measuring the height of the trash compared to measurements using a height sensor resulting in an average gap error of $0.08 \mathrm{~cm}$. While the results of the comparison of measuring waste weight using a scale in $\mathrm{kg}$ compared to measuring waste weight using a weight sensor resulted in an average gap error of $0.03 \mathrm{~kg}$. The test results are close to the actual height and weight of the garbage. The main contribution of this research is a system to monitor the volume of waste in the trash that can be linked to the application of waste collection service management for residential environments. Smart trash can users can monitor the condition of the waste by looking at the high level and weight indicators of the waste on the web application when it reaches the maximum then sending an order message to the waste collection manager for waste.
\end{abstract}

Keywords: IoT- Web, Height, Weight, Monitoring

\section{Introduction}

The Internet of Things is a new technology and has the potential to change human life globally in positive ways, thanks to its diverse connectivity. Currently, IoT technology has been used in various fields. One of them is to solve the waste problem in the city environment. The IoT-based waste management model has a vital performance in improving living standards and human well-being by increasing energy efficiency, improving governance and reducing costs.

The increase in population, changes in consumption patterns and the lifestyle of the Indonesian people has increased the number of waste piles, types and diversity of characteristics of waste. The increasing volume of landfills requires management (Marliani, 2015). Waste management or waste that does not use environmentally friendly waste management methods and techniques will not only have negative impacts on health, but will also greatly disrupt the preservation of environmental functions, both in residential areas, forests, rice fields, rivers and oceans. Several cities in Indonesia already have a waste recycling system that is dominated by scavengers in looking for recyclable waste that has an economic value such as paper, plastic, glass and iron to be sold by waste collectors.

However, the accumulation of garbage in various large urban settlements still occurs, as a result of waste management that has not met the principles of health, economy, engineering and good environmental considerations. Various studies on waste management systems have been carried out. Several studies have developed an IoT-based waste monitoring system that can solve the problem of household waste accumulation. Research conducted by (Harith et al., 2020) has tried to develop an IoT-based smart waste prototype to overcome the inefficiency of the waste collection system by monitoring the status of the trash cans, the location of the 
garbage trucks and their drivers and being able to analyze the waste production rate. Research (Arief and Gaol, 2017) also proposed a prototype for IOT-based waste volume monitoring that can monitor waste volume by designing a smart bin system that can detect the weight and level of waste using a load cell sensor and an ultrasonic sensor. The web-based application is used to display all waste data in the form of daily, weekly, monthly and yearly graphs via a GSM/GPRS network connection. Another study proposed by (Wijaya et al., 2017). proposes an IOT-based garbage monitoring and garbage collection system using hardware Node MCU (microcontroller board) connected to two ultrasonic sensors with a Wifi Module (ISM Band 900). The results show that the type of waste ('flat' or 'nonflat) with a certain angle of reflection can identify the waste level status in the trash ('full bin' or 'not full') via the internet in real-time which can be accessed by collectors' trash through the mobile application. Research (Anh Khoa et al., 2020) also proposed an intelligent waste management system using ultrasonic sensors and Lo Ra communication protocols and Tensor Flow-based deep learning to monitor the status of trash cans and identify and classify waste to separate waste, including metals, plastics, paper and the general public.

However, the problem is not only creating environmentally-friendly ones. The waste management system must be improved to increase the economic self-sufficiency of the community. An efficient waste management system is needed to make use of recycled waste in the household environment. Public awareness of the importance of monitoring the condition of their household waste disposal, which is always checking that the trash can is full or empty, especially for recycled waste. So that people can immediately sell their waste to various waste collection service entrepreneurs. Likewise, waste collector entrepreneurs can find out the conditions when the household garbage dumps are transported in each residential area.

In this study, a smart trash bin system and a prototype of IoT-based recycling waste management are proposed to overcome the accumulation of household recycled waste in residential areas. The system consists of a trash can monitoring system using sensors, a database server-based data management system for mobile applications and web applications and an android and web-based waste management application prototype. This system can be used by people who have smart trash cans or entrepreneurs who collect waste for further action. Thus, more recycled waste can provide benefits and save time for handling the transportation of recycled waste.

\section{Related Works}

In recent years, several studies have attempted various developments in terms of IoT-based waste monitoring and management systems. Research conducted by (Anh Khoa et al., 2020) has tried to develop an IoT-based smart waste prototype to overcome the inefficiency of the waste collection system. This study proposes a centralized intelligent waste management system using Lora Server as a cloud server, IoT server and Web Application Server with Things Board. The system can monitor the status of the trash can, the location of the garbage truck and its driver and can analyze the waste production rate. Research (Arief and Gaol, 2017) also proposed a prototype for IOT-based waste volume monitoring using an Arduino-based LinkIt ONE board and an ultrasonic sensor for the senses. The proposed system can monitor the volume of waste to its full extent and send notifications to the user. Other research also proposes a smart bin system design that can detect the weight and level of waste using a load cell sensor and an ultrasonic sensor. In this system, trash can be detected from the mobile application via the web to make it easier for officers to find out the condition of the waste. The webbased application is used to display all waste data in the form of daily, weekly, monthly and yearly graphs via a GSM/GPRS network connection.

Another example, suppose the system proposed by (Hassan et al., 2018) (Mustafa and $\mathrm{Ku}$ Azir, 2017) (Kadry et al., 2017) (Navghane et al., 2016). They proposed an IOT-based garbage monitoring and garbage collection system using node MCU hardware (microcontroller board) connected to two ultrasonic sensors with a Wifi Module. The results show that the type of waste ('flat' or 'non-flat) with a certain angle of reflection can identify the waste level status in the trash ('full bin' or 'not full') via the internet in real-time which can be accessed by collectors' trash through the mobile application. Research (Sheng et al., 2020) (Ziouzios and Dasygenis, 2019) also proposed an intelligent waste management system using ultrasonic sensors and LoRa communication protocols and Tensor Flow-based deep learning. The smart trash system bin monitors the status of the trash using an ultrasonic sensor. Lo Ra communication protocols for low-power and longdistance data transmission and Tensor Flow-based object detection to identify and classify waste to separate waste including metals, plastics, paper and the general public.

Other research (Mahajan et al., 2017) suggests that real-time monitoring of waste levels with the help of sensors and wireless communication will reduce the total number of trips required for GCV.

IoT-based research (Doraipandian, 2020) proposes intelligent irrigation systems based on the Internet of Things (IoT) and Machine Learning (ML) to be used in agriculture to solve water resource management problems.

Another IoT research (Saad et al., 2019) builds an IoT-based solar cell tracker that can be controlled via 
mobile Apps and the data can be read anywhere as long as there is an internet network.

\section{Proposed IoT-based Waste Monitoring System}

To overcome the accumulation of household waste, this study aims to design a system for detecting the weight and height of garbage in the trash in the form of a smart trash can that has a web-based interface. The system for detecting the condition of the trash can consists of 3 components, namely the trash can, the ultrasonic ping sensor, the load cell sensor and the MCU node. The stages of this research use the gradual processing method, Fig. 1 shows the stages of the research.

Based on Fig. 1, the stages of this research begin with the stage of designing the smart trash can, then testing if the smart trash can is functioning properly, then the stage of defining the requirements for the application requirements for the web. Furthermore, a needs analysis for application features is carried out, if appropriate, it will proceed to the prototype design stage. The final stage of the research is creating program code and testing prototypes using black-box testing. While the architectural system is shown in Fig. 2

Based on Fig. 2, the first component in the system Based on Fig. 1, the first component in the system is a trash can. This trash can is used to accommodate household waste which is equipped with two sensors to detect the height and weight of the trash. These two sensors are responsible for detecting the weight and height of the trash that enters the trash. There are 2 types of sensors used: (1) ping ultrasonic sensor, to detect the height of waste and (2) load cell sensor, to detect the weight of waste. These two sensors will send data on the weight and height of waste and be processed by node MCU. Furthermore, data on the weight and height of waste will be sent by the MCU Node component via the internet network and stored into the database server. The application component is designed using the PHP programming language for a web base supported by a web server component and Google Maps API to produce web-based applications.

This study aims to propose a monitoring system for the condition of waste in trash bins known as IoT-based smart trash cans. The proposed system is used to monitor the weight and height of household waste in trash cans. The proposed smart trash bin system is illustrated in Fig. 3.

Based on Fig. 3, the sensor detects the height and weight of the garbage, received and processed at the MCU Node and then sent to the database. based on data stored in the database, waste level information is displayed through a web application. Detection will stop if the waste level has reached the maximum.

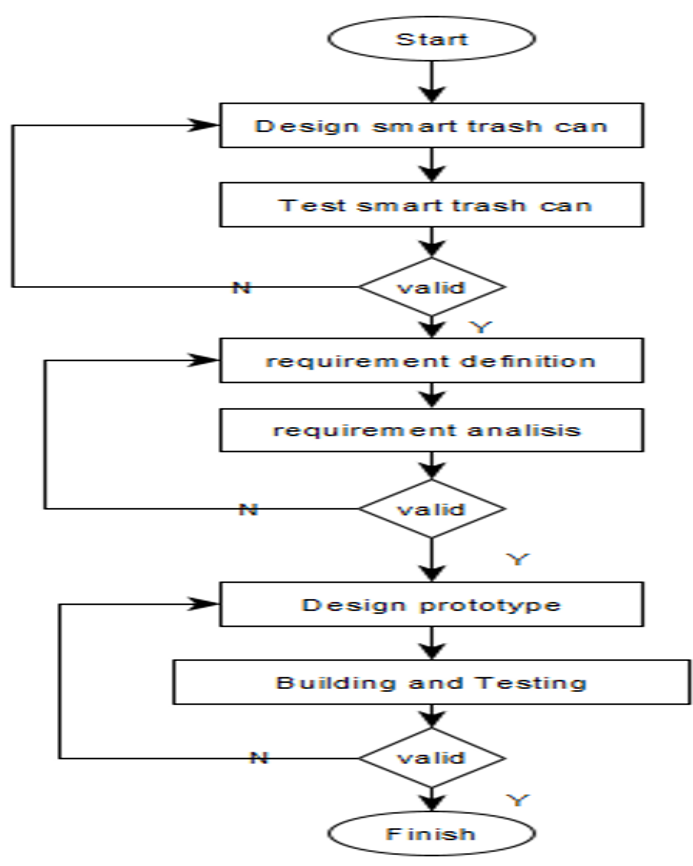

Fig. 1: shows the stages of the research

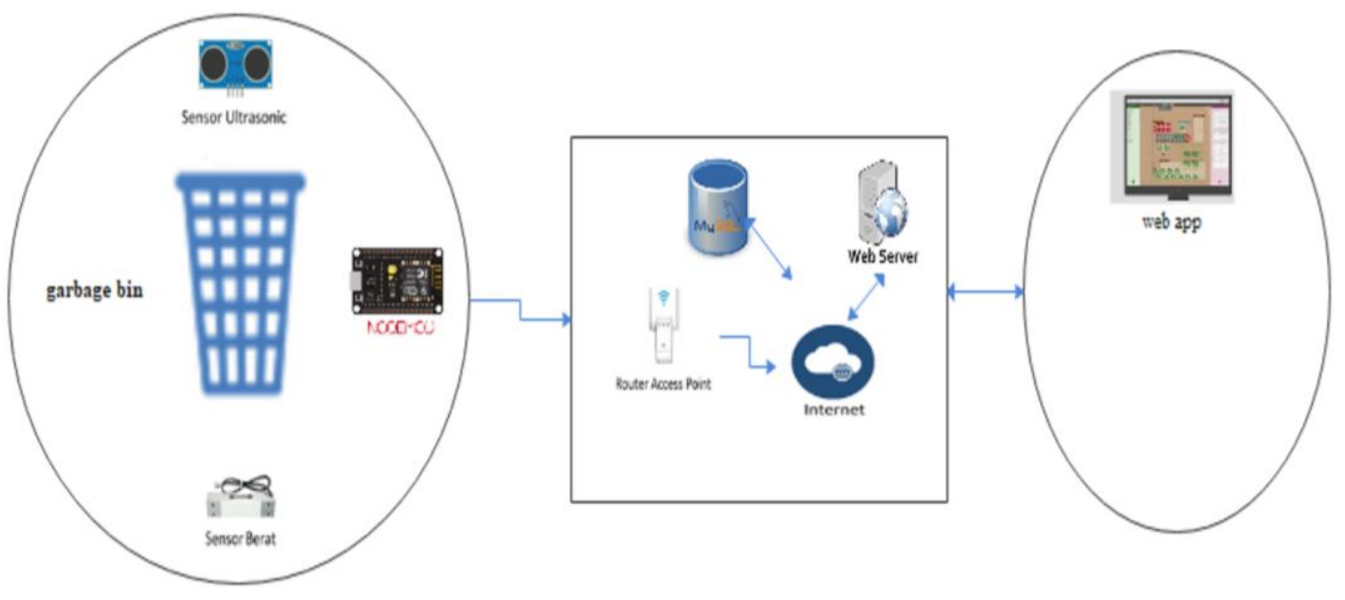

Fig. 2: System architecture 


\section{Experimental Results}

After observing the user's need to have a smart trash that can monitor the condition of the waste, the researchers designed a smart trash can using 2 sensors to detect the weight and height of the garbage. A smart trash bin with Ultrasonic Sensor is shown in Fig. 4.

Based on Fig. 4, Garbage that enters the trash can will be detected through two sensors, namely the height sensor and the weight sensor. The height sensor will detect how high the trash is in the trash can. The weight sensor will detect how much trash weighs in the bin. The data that has been read by each sensor will be sent to the MCU node then the MCU node will send the data to the database server via the internet network. Trash condition is said to be full if it has reached a maximum height of $40 \mathrm{~cm}$ and a weight of $20 \mathrm{~kg}$ and is displayed on a web application.

\section{Interface Application}

The web application interface to visually see the garbage level when it is fully detected is shown in Fig. 5.

Based on Fig. 5, the user must log in first before seeing the condition of the waste level in the trash can. The condition of the level of trash in the trash cans detected by the ultrasonic sensor is displayed in the form of a percentage while the weight of the waste is displayed in $\mathrm{kg}$. If the trash in the bin is not full, the status is "waste ready", when it is full, the status is "waste full".

\section{System Testing}

System testing carried out on a trash can that is installed with sensors and also on Android runs very well. System testing has produced data following what happened. With the data obtained in real-time, it is also very helpful in monitoring the trash, so that the owner of the trash and the cleaning staff will know the information quickly whether the trash can is full or not directly. In some factors, the tools used in processing waste require a connection to the internet using WIFI, so that if there is no internet network, data delivery is in the cloud. Testing of waste height measurement uses the ultrasonic sensor.

Table 1 shows the results of measuring the height of the trash in the trash can manually using a ruler with the measurement results from the ultrasonic sensor.

Based on Table 1 the comparison of the measurement results in an average error gap of $0,08 \mathrm{~cm}$. This shows that the results of the measurement of the waist height using the ultrasonic sensor are close to the actual waste height conditions. The Ultrasonic Sensor Measurement Chart is shown in Fig. 6.

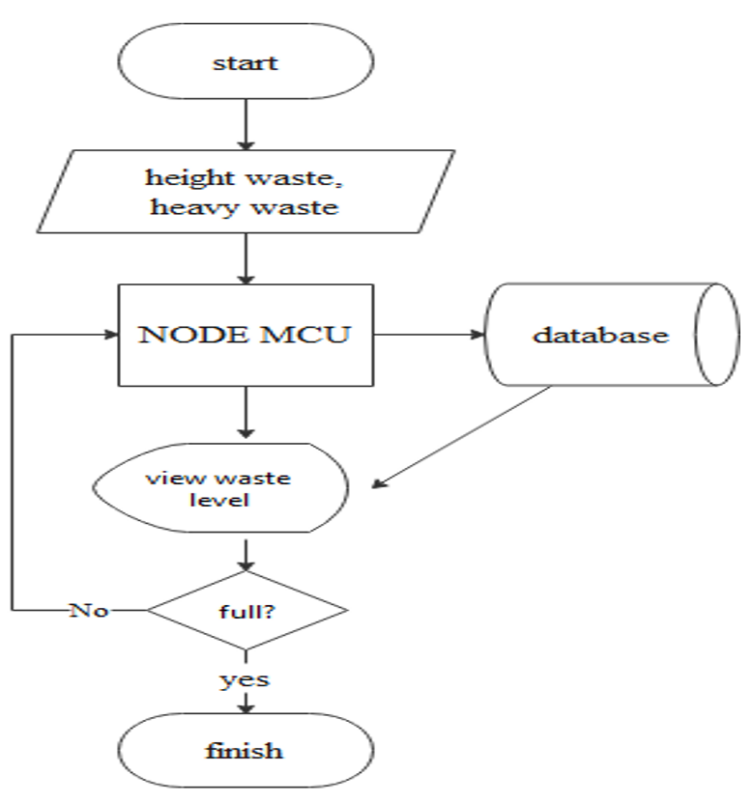

Fig. 3: Smart trash bin system

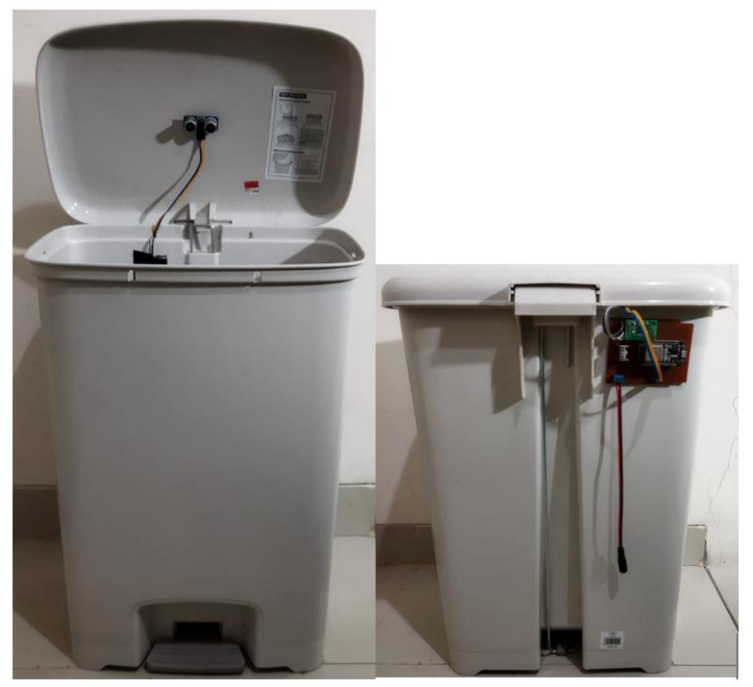

Fig. 4: Smart trash bin with ultrasonic sensor

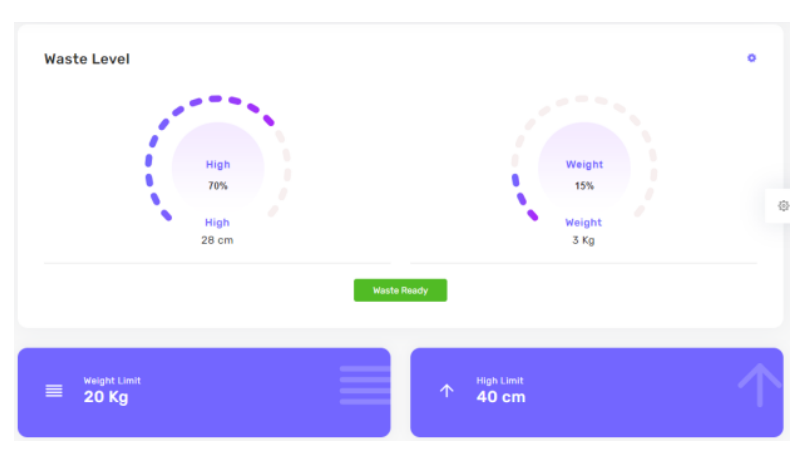

Fig. 5: Heigh and weight level interface 
Tedi Gunawan et al. / Journal of Computer Science 2021, 17 (11): 1085.1092 DOI: $10.3844 /$ jessp.2021.1085.1092

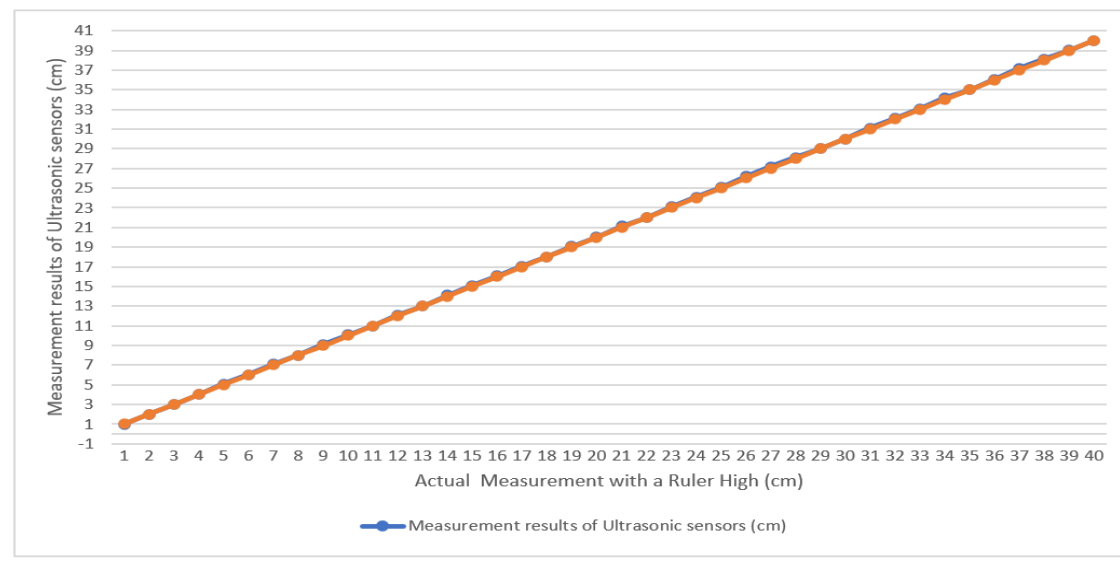

Fig. 6: Chart ultrasonic sensor measurement

Table 1: Ultrasonic sensor measurement results

\begin{tabular}{|c|c|c|c|}
\hline No & $\begin{array}{l}\text { Manual measurement } \\
\text { with a ruler high }(\mathrm{cm})\end{array}$ & $\begin{array}{l}\text { Measurement results of } \\
\text { ultrasonic sensors }(\mathrm{cm})\end{array}$ & Error $(\mathrm{cm})$ \\
\hline$\overline{1}$ & 1 & 0,98 & 0,02 \\
\hline 2 & 2 & 2,01 & $-0,01$ \\
\hline 3 & 3 & 2,98 & 0,02 \\
\hline 4 & 4 & 4,02 & $-0,02$ \\
\hline 5 & 5 & 5,1 & $-0,1$ \\
\hline 6 & 6 & 6,01 & $-0,01$ \\
\hline 7 & 7 & 7,12 & $-0,12$ \\
\hline 8 & 8 & 8,01 & $-0,01$ \\
\hline 9 & 9 & 9,11 & $-0,11$ \\
\hline 10 & 10 & 10,11 & $-0,11$ \\
\hline 11 & 11 & 11,01 & $-0,01$ \\
\hline 12 & 12 & 12,1 & $-0,1$ \\
\hline 13 & 13 & 13,01 & $-0,01$ \\
\hline 14 & 14 & 14,12 & $-0,12$ \\
\hline 15 & 15 & 15,1 & $-0,1$ \\
\hline 16 & 16 & 16,1 & $-0,1$ \\
\hline 17 & 17 & 17,1 & $-0,1$ \\
\hline 18 & 18 & 18,01 & $-0,01$ \\
\hline 19 & 19 & 19,1 & $-0,1$ \\
\hline 20 & 20 & 20,01 & $-0,01$ \\
\hline 21 & 21 & 21,13 & $-0,13$ \\
\hline 22 & 22 & 22,01 & $-0,01$ \\
\hline 23 & 23 & 23,1 & $-0,1$ \\
\hline 24 & 24 & 24,11 & $-0,11$ \\
\hline 25 & 25 & 25,1 & $-0,1$ \\
\hline 26 & 26 & 26,21 & $-0,21$ \\
\hline 27 & 27 & 27,2 & $-0,2$ \\
\hline 28 & 28 & 28,11 & $-0,11$ \\
\hline 29 & 29 & 29,01 & $-0,01$ \\
\hline 30 & 30 & 30,01 & $-0,01$ \\
\hline 31 & 31 & 31,1 & $-0,1$ \\
\hline 32 & 32 & 32,12 & $-0,12$ \\
\hline 33 & 33 & 33,1 & $-0,1$ \\
\hline 34 & 34 & 34,2 & $-0,2$ \\
\hline 35 & 35 & 35,01 & $-0,01$ \\
\hline 36 & 36 & 36,1 & $-0,1$ \\
\hline 37 & 37 & 37,21 & $-0,21$ \\
\hline 38 & 38 & 38,12 & $-0,12$ \\
\hline 39 & 39 & 39,01 & $-0,01$ \\
\hline 40 & 40 & 40,01 & $-0,01$ \\
\hline
\end{tabular}


Tedi Gunawan et al. / Journal of Computer Science 2021, 17 (11): 1085.1092 DOI: 10.3844/jessp.2021.1085.1092

Table 2: Load cell sensor measurement results

\begin{tabular}{llll}
\hline No & Litter weight $(\mathrm{Kg})$ & Measurement results of load cell sensors $(\mathrm{kg})$ & Error $(\%)$ \\
\hline 1 & 1 & 0,98 & $-2,00$ \\
2 & 2 & 2,01 & 0,50 \\
3 & 3 & 2,92 & $-2,67$ \\
4 & 4 & 4,01 & 0,25 \\
5 & 5 & 5,01 & 0,20 \\
6 & 6 & 6,1 & 1,67 \\
7 & 7 & 7,12 & 1,71 \\
8 & 8 & 8,11 & 1,37 \\
9 & 9 & 8,97 & $-0,33$ \\
10 & 10 & 9,98 & $-0,20$ \\
11 & 11 & 11,01 & 0,09 \\
12 & 12 & 12,02 & 0,17 \\
13 & 13 & 12,98 & $-0,15$ \\
14 & 14 & 14,02 & 0,14 \\
15 & 15 & 15,01 & 0,07 \\
16 & 16 & 16,11 & 0,69 \\
17 & 17 & 17,13 & 0,76 \\
19 & 18 & 18,01 & 0,06 \\
20 & 19 & 19,01 & 0,05 \\
\hline
\end{tabular}

Table 3: Black box testing results

\begin{tabular}{|c|c|c|c|c|c|}
\hline No & Testing scenarios & Test case & Expected results & Test results & Conclusion \\
\hline 1 & $\begin{array}{l}\text { Input waste weight data from } \\
\text { the ultrasonic sensor }\end{array}$ & $\begin{array}{l}\text { View box trash weight level } \\
\text { indicator in } \mathrm{cm} \text { and percentage units }\end{array}$ & $\begin{array}{l}\text { A number that shows the } \\
\text { weight of real waste appears }\end{array}$ & $\begin{array}{l}\text { A number appears that } \\
\text { shows the weight of } \\
\text { waste from the measurement } \\
\text { results of the ultrasonic sensor } \\
\text { with a figure close to the actual } \\
\text { condition }\end{array}$ & OK \\
\hline 2 & $\begin{array}{l}\text { High data input of garbage } \\
\text { from load cell sensor }\end{array}$ & $\begin{array}{l}\text { View the waste level indicator } \\
\text { in } \mathrm{kg} \text { and percentage units }\end{array}$ & $\begin{array}{l}\text { A number appears that shows the } \\
\text { high level of waste according to } \\
\text { the condition which has been real } \\
\text { converted from units of kg into } \\
\text { a percentage }\end{array}$ & $\begin{array}{l}\text { A number appears that shows the height } \\
\text { of waste from the measurement results of } \\
\text { the load cell sensor in the form of a } \\
\text { percentage of the waste weight indicator } \\
\text { level with a number close to the actual } \\
\text { condition }\end{array}$ & OK \\
\hline 3 & $\begin{array}{l}\text { Input from waste weight or } \\
\text { height not in max limit }\end{array}$ & $\begin{array}{l}\text { View the waste level } \\
\text { indicator waste ready }\end{array}$ & $\begin{array}{l}\text { An indicator on the } \\
\text { web waste ready }\end{array}$ & An indicator on the web waste ready & OK \\
\hline 4 & $\begin{array}{l}\text { Input from max waste } \\
\text { weight or height }\end{array}$ & $\begin{array}{l}\text { View the waste level } \\
\text { indicator waste full }\end{array}$ & $\begin{array}{l}\text { An indicator on the web waste } \\
\text { ready change to waste full }\end{array}$ & $\begin{array}{l}\text { An indicator on the web waste ready } \\
\text { change to waste full }\end{array}$ & OK \\
\hline
\end{tabular}

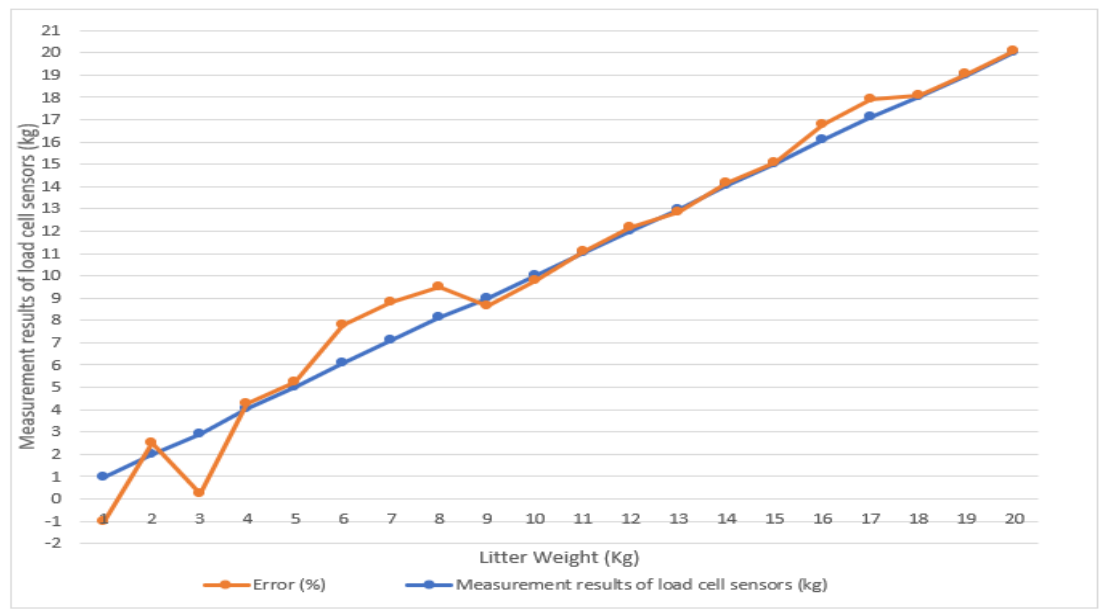

Fig. 7: Load cell sensor measurement 
Table 2 shows the results of measuring the weight of the trash in the trash manually using a weighing scale with measurement results from the Load Cell Sensor.

Base Table 2 shows the results of measuring the weight of waste using a load cell sensor. In the column, the weight of waste is the measurement of real waste from the scale in $\mathrm{kg}$. in the load cell sensor measurement results column is the result of measuring the weight of waste using a load cell sensor in $\mathrm{kg}$. The results of the measurement comparison show an average error of $0,03 \mathrm{~kg}$... The load cell sensor measurement graph is shown in Fig. 7.

Furthermore, the results of testing a web application that displays the weight and height of the garbage in the trash using the black box test are shown in the Table 3 .

\section{Discussion and Future Work}

Several studies that have been proposed by (Hassan et al., 2018) (Mustafa and Ku Azir, 2017) (Kadry et al., 2017) (Navghane et al., 2016) propose a similar system for monitoring and waste collection based on IoT waste. using hardware Node MCU (microcontroller board) which is connected to two ultrasonic sensors with Wifi Module. The results can identify the status of the level of waste in the trash ('full bin' or 'not full') via the internet in real-time which can be accessed by scavengers through a mobile application. The difference in this study results in a waste monitoring system in the form of a smart trash that can display the level of waste volume in the trash can through a web application and can be integrated with a waste management application that is accessed by waste collector entrepreneurs so that smart trash can users get economic value from selling their waste.

\section{Conclusion}

This research resulted in a household trash can monitoring system. The proposed system consists of 3 important parts, the first namely an IoT-based household trash can monitor system. Second, the waste bin monitoring system is in the form of a smart trash can using 2 sensors, namely an ultrasonic sensor and a load cell sensor. Third, displays a full indicator on the web if it has reached the maximum height or weight limit of the garbage.

The ultrasonic sensor will detect how high the garbage is in the trash. The load cell sensor will detect the weight of the garbage that goes to the right garbage. Furthermore, the MCU node is a processor and sender of data into the internet network. Smart trash cans equipped with sensors and MCU nodes have been tested manually using a ruler for measuring the height of the garbage, resulting in an average gap error of 0,08 $\mathrm{cm}$ close to the actual height of the garbage. While the results of measuring the weight of real waste using a scale in $\mathrm{kg}$, the results of the comparison of measurements show a gap error of $0.03 \mathrm{~kg}$. Testing of several test cases from web applications is carried out using the black box testing method with the test results as expected by the user. This study has limitations, first, smart trash cans cannot sort out various types of waste automatically, so the owner of the bin must collect garbage according to its type into the bin manually. For further research, improvements are made to overcome the above limitations, including developing smart trash bins so that they can detect the type of waste.

\section{Author's Contributions}

Tedi Gunawan: Design the research plan, Coordinated the data, the writing of the manuscript

Elis Hernawati and Bayu Rima Aditya: Coordinated the data, the writing of the manuscript

\section{Ethics}

This article is original and contains unpublished material. The corresponding author confirms that all of the other authors have read and approved the manuscript and no ethical issues involved.

\section{References}

Anh Khoa, T., Phuc, C. H., Lam, P. D., Nhu, L. M. B., Trong, N. M., Phuong, N. T. H., ... \& Duc, D. N. M. (2020). Waste management system using IoT-based machine learning in university. Wireless Communications and Mobile Computing, 2020. doi.org/10.1155/2020/6138637

Arief, M. F., \& Gaol, F. L. (2017, June). Developing and Evaluating Prototype of Waste Volume Monitoring Using Internet of Things. In IOP Conference Series: Materials Science and Engineering (Vol. 215, No. 1, p. 012038). IOP Publishing. doi.org/10.1088/1757$899 X / 215 / 1 / 012038$

Doraipandian, M. (2020). IoT Framework for Smart Irrigation using Machine Learning Technique. doi.org/10.3844/jcssp.2020.355.363

Harith, M. Z. M. Z., Hossain, M. A., Ahmedy, I., Idris, M. Y. I., Soon, T. K., \& Noor, R. M. (2020). Prototype Development of IoT Based Smart Waste Management System for Smart City. IOP Conference Series: Materials Science and Engineering, 884(1). doi.org/10.1088/1757-899X/884/1/012051

Hassan, H., Saad, F., Fazlin, N., \& Aziz, A. (2018). Waste Monitoring System based on Internet-ofThing (IoT). Proceedings - 2018 IEEE Conference on Systems, Process and Control, ICSPC 2018, December, 187-192. doi.org/10.1109/SPC.2018.8704142 
Kadry, S., Ramasamy, L. K., Mukhopadhyay, S. C., Islam, T., \& Haigh, P. A. (2017). Garbage monitoring system using IoT Garbage monitoring system using IoT. doi.org/10.1088/1757-899X/263/4/042027

Mahajan, P. S. A., Kokane, A., Shewale, A., Shinde, M., \& Ingale, S. (2017). Smart Waste Management System using IoT. International Journal of Advanced Engineering Research and Science, 4(4), 93-95. doi.org/10.22161/ijaers.4.4.12

Marliani, N. (2015). Pemanfaatan Limbah Rumah Tangga (Sampah Anorganik) Sebagai Bentuk Implementasi dari Pendidikan Lingkungan Hidup. Formatif: Jurnal Ilmiah Pendidikan MIPA, 4(2), 124-132. doi.org/10.30998/formatif.v4i2.146

Mustafa, M. R., \& Ku Azir, K.N.F (2017). Smart Bin: Internet-of-Things Garbage Monitoring System. 01030, 1-4. doi.org/10.1051/matecconf/201714001030

Navghane, S. S., Killedar, M. S., \& Rohokale, V. M. (2016). IoT Based Smart Garbage and Waste Collection Bin. International Journal of Advanced Research in Electronics and Communication Engineering, 5(5), 1576-1578.

http://ijarece.org/wp-

content/uploads/2016/06/IJARECE-VOL-5-ISSUE5-1576-1578.pdf
Saad, A. F., Ibrahim, M., Damanhuri, M., \& Yusuf, N. I. (2019). Developing a Prototype for Sun Tracker System Based on IoT: Controlled by Mobile App and Online Database Monitoring. doi.org/10.3844/ajassp.2019.11.25

Sheng, T. J., Islam, M. S., Misran, N., Baharuddin, M. H., Arshad, H., Islam, M. R., Chowdhury, M. E. H., Rmili, H., \& Islam, M. T. (2020). An Internet of Things Based Smart Waste Management System Using LoRa and Tensorflow Deep Learning Model. IEEE Access, 8, 148793-148811. doi.org/10.1109/ACCESS.2020.3016255

Wijaya, A. S., Zainuddin, Z., \& Niswar, M. (2017). Design a smart waste bin for smart waste management. Proceedings of the 2017 5th International Conference on Instrumentation, Control and Automation, ICA 2017, 62-66. doi.org/10.1109/ICA.2017.8068414

Ziouzios, D., \& Dasygenis, M. (2019). A Smart Bin Implementantion using LoRa. 2019 4th South-East Europe Design Automation, Computer Engineering, Computer Networks and Social Media Conference (SEEDA-CECNSM), 1-4. doi.org/10.1109/SEEDA-CECNSM.2019.8908523 